\title{
電気化学への入口
}

\section{大山 順也（名古屋大学大学院工学研究科）}

私は, つい今年の 3 月に初めて電気化学会で発表させ ていただきました新参者で，電気化学の素人です。この 「電気化学への入り口」を書く機会を与えていただいて, いままでの研究を振り返り，いつ初めて電気化学に触れ たのかを考えました。私が学生の時に所属していた研究 室の研究対象の1つは, 光触媒でした。その中で私は, 光電析 (光析出, 光めつき) 法で酸化チタン光触媒上に 生成する金属ナノ粒子の生成メカニズムについての研 究を行っていました。 今から思えば, この研究が, 初め ての電気化学に関する研究です。

金属ナノ粒子の生成メカニズムと合成に関する研究で 博士の学位を取得したあと，2011 年 4 月に名古屋大学の 薩摩篤先生の研究室に助教として着任いたしました。薩 摩研では, 銀クラスターを用いた自動車排ガス浄化や, 銀ナノ粒子を用いた有機合成が行われており，銀触媒を 燃料電池電極触媒へ展開しょうとしているところでした。 私は，着任してから新しいことを始めたいと思っていた ので, 電極触媒の研究をしたいと申し出て, 燃料電池電 極触媒の研究を始めることになりました。研究室には, 四回生で然料電池触媒について卒業研究を行い, そのま ま進学する学生が 1 人おり, また新しく燃料電池触媒を 研究したいと言う学生が 2 人研究室に入ってきました。 これにより, 薩摩研燃料電池電極触媒グループは, 教員 を含めて構成人数 5 人となりました。薩摩研では，私が 着任する前に，アンモニアセンサーを研究していたので すが，燃料電池の研究については始めたばかりです。つ まり, 我々の電極触媒グループは, 燃料電池電極触媒に ついてほぼ何も知らない人間の集まりでした。こいう状 況でしたので, グループの学生は, 自分達で然料電池触 媒の研究を立ち上げるぞ, という気持ちで勉強し, 積極 的に学会へ参加して情報を集め出しました（現在進行形）. 新しい分野の研究を始めるのは大変ですが, 一緒に勉強 しながら研究するのは楽しいものです.

我々の研究対象は, アニオン交換膜型燃料電池触媒で す。私は，博士課程で金属ナノ粒子の合成を行っていま したので，触媒材料として，金属および金属酸化物のナ ノ粒子，特に，白金以外の金属を検討しました。また， 金属触媒の構造, 化学状態を詳細にキャラクタリゼー ションし，これらが触媒活性におよぼす影響に注目して
研究を進めました。触媒合成やキャラクタリゼーション は共通なのである程度すんなり進めることができるので すが，電気化学測定とその評価は大きな壁となりました. 研究結果をまとめ, 論文投稿してみると, レフリーから 電気化学測定と触媒活性の評価について指摘があるので す。既報の論文通り測定して評価していたつもりなので すが，それではダメで，きちんと測定，評価する方法が あるとの指摘です。レフリーの指導に従って, 実験をや り直し, 再度投稿し, またおかしなところを指摘される ということを繰り返しました。一度, 方向を見誤ってし まい，何をどうすればよいのか分からなくなった時に， 専門の先生方に泣きつき，ご指導いただきました。電気 化学は自分に合ってなさそうだ, やめようかなとさえ思 いましたが, 先生方のご指導のおかげで, ようやく論文 が通ったときには，心からうれしかったです。誠に有難 うございました。今やっと一歩踏み出せたのかなとは 思っていますが, これは始まりで, まだまだ電気化学測 定と評価について学ばなければいけないことがあります. 今度, 大変有難いことに, 専門の先生のところで, はじ めから電気化学測定と評価について勉強させていただけ ることになりました。電気化学の入口に戻るわけです. ただ， 3 年前は裏門から（塀を超えて?）入りましたが, 今度は正門の入口です。

いま我々は電気化学の入口にいます。皆様, 今後とも ご指導ご鞭撻のほど何卒宜しくお願い申し上げます.

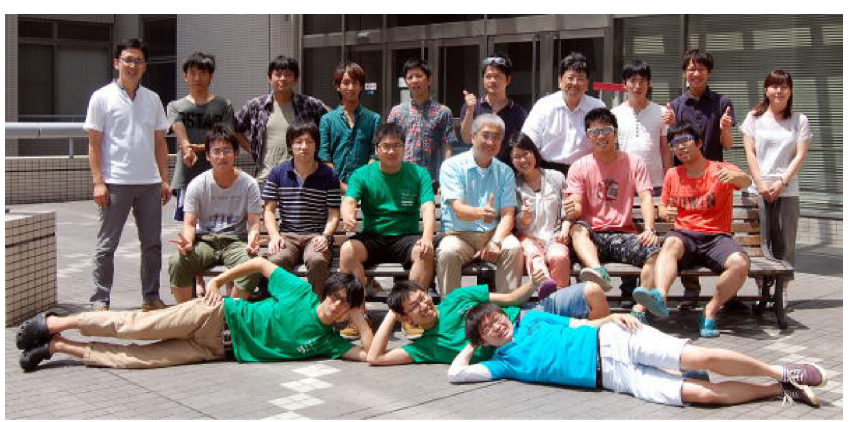

Figure 1. (Color online) 2013 年薩摩研の集合写真（筆者： 最後列一番左) 